\title{
Anakinra in the treatment of rheumatoid arthritis in adult patients with an inadequate response to methotrexate. Systematic review and meta-analysis
}

\author{
Anakinra w leczeniu reumatoidalnego zapalenia stawów u dorosłych, \\ u których nie uzyskano wystarczającej odpowiedzi na leczenie metotreksatem. \\ Przegląd systematyczny i metaanaliza
}

\author{
Paweł Kawalec ${ }^{1}$, Przemysław Holko², Anna Paszulewicz ${ }^{3}$ \\ 1Drug Management Department, Institute of Public Health, Faculty of Health Sciences, Jagiellonian University, Cracow \\ 2Department of General Biochemistry, Faculty of Biochemistry, Biophysics and Biotechnology, Jagiellonian University, Cracow \\ ${ }^{3}$ Laboratory of Cell Biophysics, Faculty of Biochemistry, Biophysics and Biotechnology, Jagiellonian University, Cracow \\ IZakład Gospodarki Lekiem, Instytut Zdrowia Publicznego, Wydział Nauk o Zdrowiu, Uniwersytet Jagielloński, Kraków \\ 2Zakład Biochemii Ogólnej, Wydział Biochemii, Biofizyki i Biotechnologii, Uniwersytet Jagielloński, Kraków \\ 3Pracownia Biofizyki Komórki, Wydział Biochemii, Biofizyki i Biotechnologii, Uniwersytet Jagielloński, Kraków
}

Key words: interleukin-1, interleukin-1 receptor antagonist, anakinra, rheumatoid arthritis.

Stowa kluczowe: interleukina 1, antagonista receptora interleukiny 1, anakinra, reumatoidalne zapalenie stawów.

\section{Sum mary}

Background: Anakinra is an interleukin-1 receptor antagonist (IL-1Ra) that blocks the biological activity of IL-1, including inflammation. Anakinra in combination with methotrexate (MTX) is indicated for reduction in signs and symptoms in active rheumatoid arthritis, in adults who have failed one or more disease-modifying antirheumatic drugs (DMARDs).

Material and methods: According to the rules of evidence-based medicine popularized by The Cochrane Collaboration, a systematic review of medical literature has been performed in order to assess clinical efficacy and safety of the therapy. The review yielded three randomized clinical studies which compared the administration of anakinra in combination with MTX (or other DMARDs) to placebo with MTX.

Results: Moderate clinical efficacy defined as ACR20, ACR50 and ACR70 response and safety profile of anakinra in combination with MTX or other DMARDs was proven in most studies mentioned and confirmed by the results of the meta-analysis performed.

Conclusions: Injection site reactions were the most common adverse events frequently leading to withdrawal.

\section{Streszczenie}

Wstęp: Anakinra jest rekombinowanym ludzkim antagonistą receptora interleukiny 1 (IL-1Ra), który prowadzi do zahamowania aktywności biologicznej IL-1, m.in. działania prozapalnego. Anakinra w skojarzeniu z metotreksatem (MTX) jest zalecana w leczeniu przedmiotowych i podmiotowych objawów reumatoidalnego zapalenia stawów (RZS) u dorosłych pacjentów, u których zastosowanie jednego lub więcej leków modyfikujących przebieg choroby (LMPCh) nie przyniosło pożądanych efektów. Materiał i metody: W celu oceny skuteczności klinicznej tej opcji terapeutycznej, zgodnie z zasadami medycyny opartej na dowodach naukowych (evidence based medicine -EBM) zalecanymi przez organizację The Cochrane Collaboration oraz polską Agencję Oceny Technologii Medycznych (AOTM), dokonano systematycznego przeglądu literatury medycznej, w wyniku którego odnaleziono łącznie trzy badania kliniczne z randomizacją dotyczące porównania anakinry stosowanej z MTX (lub innymi LMPCh) względem placebo podawanego z MTX.

Wyniki: Umiarkowana skuteczność kliniczna wg kryteriów ACR20, ACR50, ACR70 i bezpieczeństwo stosowania anakinry w terapii skojarzonej u pacjentów z RZS została potwierdzona w większości odnalezionych badań oraz dodatkowo na podstawie wyników metaanaliz przeprowadzonych z wykorzystaniem wyników przeglądu systematycznego. Wnioski: Najczęstszym występującym działaniem niepożądanym, które w wielu przypadkach było przyczyną rezygnacji z dalszego leczenia, było pojawienie się reakcji alergicznej w miejscu wstrzyknięcia leku.

\section{Adress for correspondence:}

dr n. med. Paweł Kawalec, Zakład Gospodarki Lekiem, Instytut Zdrowia Publicznego, Wydział Nauk o Zdrowiu, Uniwersytet Jagielloński, ul. Grzegórzecka 20, 31-531 Kraków, tel. +48 1242413 90, fax +48 12421 74 47, e-mail: pawel.kawalec@uj.edu.pl

Submitted: 26.11 .2012 


\section{Introduction}

Rheumatoid arthritis (RA) is a chronic, systemic disease of the connective tissue, characterized by inflammation of the synovial membrane, non-specific inflammation of symmetric joints, the presence of extra-articular changes, and systemic complications, leading to disability, handicap and premature death [1, 2]. Rheumatoid arthritis has a multifactorial aetiopathogenesis [3], but it is believed that initiation of the disease is linked to the activation of T-lymphocytes and macrophages, which are responsible for amplifying and sustaining an abnormal inflammatory response through the release of pro-inflammatory cytokines [4]. The level of interleukin-1 (IL-1) in the synovial membrane or serum correlates with disease activity in the respective joints [5]. In recent years, decreasing the activity of pro-inflammatory cytokines, including IL-1, has become the goal of new biological therapies used in the treatment of RA.

Anakinra, which belongs to the group of biological drugs, is a recombinant human competitive antagonist of the IL-1 receptor (IL-1Ra), and its administration to patients with RA results in a positive response to treatment in regard to reduced prostaglandin $\mathrm{E}_{2}$ release, metalloproteinase production (collagenase and stromelysin), and the degree of proteoglycan degradation $[6,7]$.

According to the most recent recommendations regarding clinical practice in Poland, biological drugs, among them rituximab and abatacept, are used as additional treatment in patients in whom therapy using traditional disease-modifying anti-rheumatic drugs (DMARDs) was ineffective [2]. It should be noted that the use of anakinra was not included in the 2008 Guidelines on Clinical Practice in Poland [2] discussed here, nor in the current specifications of the drug programme outlining administration of biological drugs to patients with RA and juvenile idiopathic arthritis (JIA), who failed to respond to treatment with at least two diseasemodifying anti-rheumatic drugs [8]. In accordance with the 2010 EULAR (European League Against Rheumatism) recommendations $[9,10]$, anakinra is not recommended for use in the treatment of patients with RA because of a lack of sufficient data on the drug's effectiveness. It should be added that in the age of extended-action biological drugs (adalimumab, etanercept, infliximab, and rituximab), administered at intervals of several weeks or months [8], anakinra, which must be administered subcutaneously on a daily basis, is only used sporadically.

The aim of this study was to provide scientific evidence for the clinical effectiveness and safety of anakinra used in combination with methotrexate (MTX) or other diseasemodifying anti-rheumatic drugs for the treatment of RA.

\section{Material and methods}

In order to assess the clinical effectiveness of the use of anakinra in combination with MTX, a systematic review of medical literature was conducted by searching the MEDLINE (PubMed), EMBASE and Cochrane databases for indexed publications, published up until the $20^{\text {th }}$ of April 2012, regarding anakinra in the treatment of the objective and subjective symptoms of RA in adults. The review was conducted in accordance with the standards of scientific evidence-based medicine (EBM) recommended by The Cochrane Collaboration [11] and the Polish Agency for Health Technology Assessment (Agencja Oceny Technologii Medycznych - AOTM) [12]. The search strategy consisted of the following key words, linked together by logical Boolean operators: (rheumatoid arthritis OR arthritis deformans OR arthrosis deformans OR rheumatic arthritis) in regard to population AND (Anakinra OR Kineret OR Antril OR IL 1 febrile inhibitor OR Interleukin 1 Inhibitor Urine OR IL-1 Inhibitor Urine OR IL 1 Inhibitor Urine OR IL-1Ra OR Recombinant interleukin 1 receptor antagonist OR Recombinant interleukin 1 receptor blocker) in regard to interventions. The results were limited to studies involving human subjects (Humans) and methodological filters were used to identify randomized clinical trials (Clinical Trials; Randomized Clinical Trials; Controlled Clinical Trials). The search was designed to identify publications in the following languages: English, Polish, French, and German. All randomized clinical trials that assessed the effectiveness and safety of the use of anakinra in combined therapy in adult patients with RA were included. After excluding all the publications that did not fulfil the thematic or methodological criteria, the search produced a total of 3 randomized clinical trials that addressed a comparison of anakinra combined with MTX vs. placebo administered with MTX: Cohen 2002 [13, 14], Cohen 2004 [15], and Bao 2011 [16] as well as one randomized clinical trial that addressed a comparison of the safety profile of anakinra, used in combination with disease-modifying drugs (among others, methotrexate) versus placebo combined with diseasemodifying drugs (among others, methotrexate) - the 2003 Fleischmann study [17, 18]. In addition, the extensive search of medical databases brought to light another nonrandomized observational study that addressed the use of anakinra in combination with MTX in patients with RA.

This review only mentions full-text publications on the above trials, published in peer-reviewed journals.

\section{Results}

The clinical effectiveness of a wide spectrum of doses of anakinra combined with MTX was assessed in the randomized 2002 Cohen trial [13, 14] (Table I). Patients (419 patients with RA) were randomly assigned to one of 6 groups, in which the participants received anakinra in doses ranging from $0.04 \mathrm{mg} / \mathrm{kg}$ b.w. to $2.0 \mathrm{mg} / \mathrm{kg}$ b.w. or placebo in the form of subcutaneous injections (Table I). After 12 and 24 weeks of treatment, a statistically significantly larger num- 


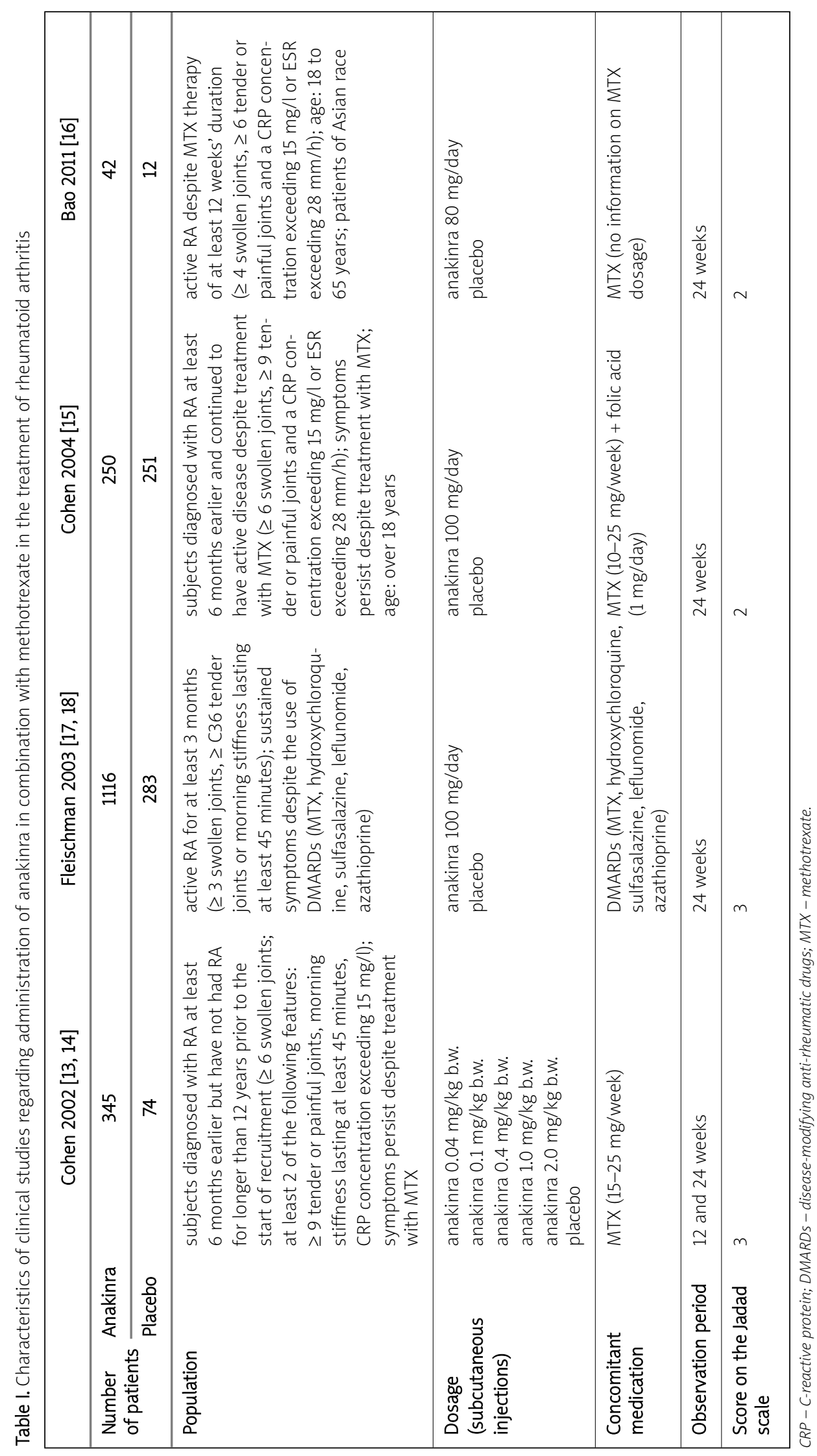


ber of patients achieved a response to treatment in accordance with criteria established by the American College of Rheumatology (ACR) - ACR20, ACR50, and ACR70 - in the groups treated with anakinra in doses of $1.0 \mathrm{mg} / \mathrm{kg}$ b.w. and $2.0 \mathrm{mg} / \mathrm{kg}$ b.w. compared to the placebo group. The results were as follows - after 12 weeks, respectively: ACR20 - 46\% vs. $19 \%$ and $38 \%$ vs. $19 \%$, ACR $50-19 \%$ vs. $4 \%$ and $24 \%$ vs. $4 \%$, and ACR70 - 5\% vs. $0 \%$ and $11 \%$ vs. $0 \%$; after 24 weeks, respectively: ACR20 - $42 \%$ vs. $23 \%$ and $35 \%$ vs. $23 \%$, ACR $50-24 \%$ vs. $4 \%$ and $17 \%$ vs. $4 \%$, and ACR70 - $10 \%$ vs. $0 \%$ and $7 \%$ vs. $0 \%$.

Observations also showed that the groups of patients receiving anakinra in doses of $1.0 \mathrm{mg} / \mathrm{kg}$ b.w. and $2.0 \mathrm{mg} / \mathrm{kg}$ b.w. had a statistically significant sustained response to treatment (defined as meeting ACR20 improvement criteria with improvement sustained over a period of at least 4 to 6 months of the study).

Overall, treatment with anakinra was well tolerated by patients and the most common adverse events were mild or moderate injection site reactions, whose occurrence was dose related. However, they were the most common reason for patient withdrawal from the study. Other commonly observed adverse reactions included headaches, upper respiratory tract infections, and mild sinusitis; therefore it was not necessary to discontinue therapy.

The clinical effectiveness and safety of anakinra at a dose of $100 \mathrm{mg} /$ day administered together with MTX was confirmed in the 24-week randomized, double blinded 2004 Cohen study [15] (Table I). Every 4 weeks patients underwent evaluation to establish changes in their clinical status and the presence of adverse events. The primary end point was ACR20 response after 24 weeks of treatment and the most important remaining end points were: changes in the individual parameters in accordance with ACR criteria, the Health Assessment Questionnaire (HAQ) score, C-reactive protein (CRP) concentration, erythrocyte sedimentation rate (ESR) value, ACR50 and ACR70 responses, and sustained ACR20 response. After 24 weeks of treatment, a statistically significant larger number of patients achieved ACR20, ACR50, and ACR70 improvement in the group treated with anakinra than in the group receiving a placebo (38\% vs. $22 \%, 17 \%$ vs. $8 \%$, and $6 \%$ vs. $2 \%$, respectively). The significance of the results with regard to ACR20 responses was confirmed by a sensitivity analysis that involved 387 patients who had completed the study (47\% vs. 29\%). Statistically significant ACR20 improvement occurred after just 4 weeks of the study, and observations revealed that a higher percentage of patients in the study group had sustained improvement compared to the placebo group ( $27 \%$ vs. $12 \%)$. It was also determined that patients treated with anakinra had an improvement in all of the components of the ACR response criteria (such as the number of tender or painful joints, disease activity evaluated by the physician and the patient, intensity of pain eval- uated by patients, CRP concentration, ESR, and HAQ score) with the exception of the number of swollen joints. It should, however, be added that at present the most important therapeutic effect associated with the use of biological drugs should be the achievement of remission or very low disease activity in a short period of time (3-6 months) [10]; therefore the fact that $6 \%$ of patients receiving anakinra over 6 months of treatment achieved an ACR70 response does not appear to be a satisfactory result. The incidence of adverse reactions at injection sites was almost 3-fold higher in the group of patients receiving anakinra than in the placebo group (65\% vs. $24 \%$ ) and these were often the reason for patient withdrawal from the study ( $8.4 \%$ vs. $0.8 \%)$, although they were judged to be of mild or moderate intensity. Both therapeutic groups had a similar incidence of other adverse events, such as infections or serious adverse events.

The results of the 2004 Cohen study confirmed the moderate clinical effectiveness and safety of anakinra at a dose of $100 \mathrm{mg} /$ day in combination with MTX and prove that the designated dose of medication is suitable for use in actual clinical practice. Among the strengths of the analysed trial, influencing the credibility of obtained results, was the good balance achieved among various potentially disruptive factors between the study arms as well as inclusion and exclusion criteria corresponding to the indications for use of the studied therapy. The period of observation, which amounted to 24 weeks, was a limiting factor; it was too short to permit an evaluation of longterm effects associated with the use of anakinra.

The next randomized, double-blinded study, conducted by Bao in 2011 [16], addressed the use of anakinra at a dose of $80 \mathrm{mg} /$ day combined with MTX (Table I). Every 4 weeks, study participants underwent evaluation to establish changes in their clinical status and the presence of adverse events. The primary end point was ACR20 response after 24 weeks of treatment and the most important remaining end points were: ACR50 and ACR70 response and improvement in DAS28 score values (European League Against Rheumatism Disease Activity Score 28). After 24 weeks of treatment, a statistically significant larger number of patients receiving anakinra achieved ACR20 improvement compared with placebo (64\% vs. 17\%). Fifteen patients in the anakinra group (36\%) failed to respond to treatment, since they did not achieve an improvement of at least $20 \%$ or else patients withdrew from the study before its completion. Moreover, the percentage of patients who met the ACR50 and ACR70 improvement criteria was higher in the group treated with anakinra than in the placebo group (38\% vs. $0 \%$ and $17 \%$ vs. $0 \%$, respectively); however, in the case of ACR70, this result was not statistically significant $(\alpha=0.05)$. In view of the most recent EULAR recommendations [10] with regard to the desired clinical effectiveness of biological therapies, it is difficult 
to consider these results satisfactory. Interestingly, observations over the 24 weeks of the study revealed that 9 out of the 42 patients receiving anakinra (21.4\%), who initially responded well to treatment, experienced a secondary reduction in the effectiveness of the treatment or failure of the therapy that led to withdrawal. The results revealed a reduction in DAS28 scores compared to baseline values in both study groups; however, the difference in the group treated with anakinra was statistically significantly larger than in the group receiving placebo.

The results of this study confirm that administration of anakinra results in improvement in patients with RA after 24 weeks of treatment, assessed according to ACR criteria. Secondary treatment failure in some patients who initially responded to treatment is a surprising development.

A multicentre (169 centres in 9 countries), randomized, double-blinded study conducted in 2003 by Fleischman $[17,18]$ assessed the safety of anakinra therapy at a dose of $100 \mathrm{mg} /$ day administered over 6 months as adjuvant therapy to patients with RA treated with DMARDs (Table I). Patients were characterised by large differences in their RA activity and concomitant treatment (30\% - MTX, 22\% - MTX + another DMARD, 21\% - no DMARDs, 47\% - DMARDs + corticosteroids, and $10.5 \%$ - none of the above medications). The majority of patients complied with their physicians' recommendations and over $90 \%$ of them took at least $90 \%$ of their prescribed drug doses. In the group treated with anakinra, the incidence of allergic-inflammatory injection site reactions was significantly higher compared to the group receiving the placebo $(72.6 \%$ vs. $32.9 \%)$, but the majority of these were transient reactions of mild or mod- erate intensity. An increase in RA symptom severity was observed in $20 \%$ of patients who experienced adverse events in the group treated with anakinra and in $27.6 \%$ of patients in the placebo group (the differences were not statistically significant). Furthermore, no statistically significant differences between groups were noted with regard to the risk of death, serious and severe adverse events, and withdrawal from treatment as a result of adverse events and infections. The incidence of serious infections during the course of anakinra therapy was significantly higher than with the placebo ( $2.1 \%$ vs. $0.4 \%$ ). The results of the presented study confirm that the safety of anakinra administered to patients with RA is relatively high. The purpose of including a large number of patients in this study was to identify potential rare serious adverse events.

A meta-analysis of the results of clinical trials presented in this review was conducted in order to assess the clinical effectiveness and safety of anakinra after 24 weeks of treatment. The meta-analyses examined a more diverse patient population than that of each individual study (with regard to stages of the disease, patient age, racial group, and adjuvant medications) as well as a more diverse range of doses of anakinra. Effectiveness was assessed based on a meta-analysis for ACR20 response (relative risk), ACR50 and $A C R 70$ response (odds ratio calculated using the Peto method due to the absence of a particular end point in at least one of the groups) and produced a statistically significant result for each of these end points that confirmed the moderate effectiveness of anakinra in the examined dose range (1-2 mg/kg b.w. per day, $80 \mathrm{mg} /$ day, and 100 $\mathrm{mg} /$ day) combined with methotrexate in patients with

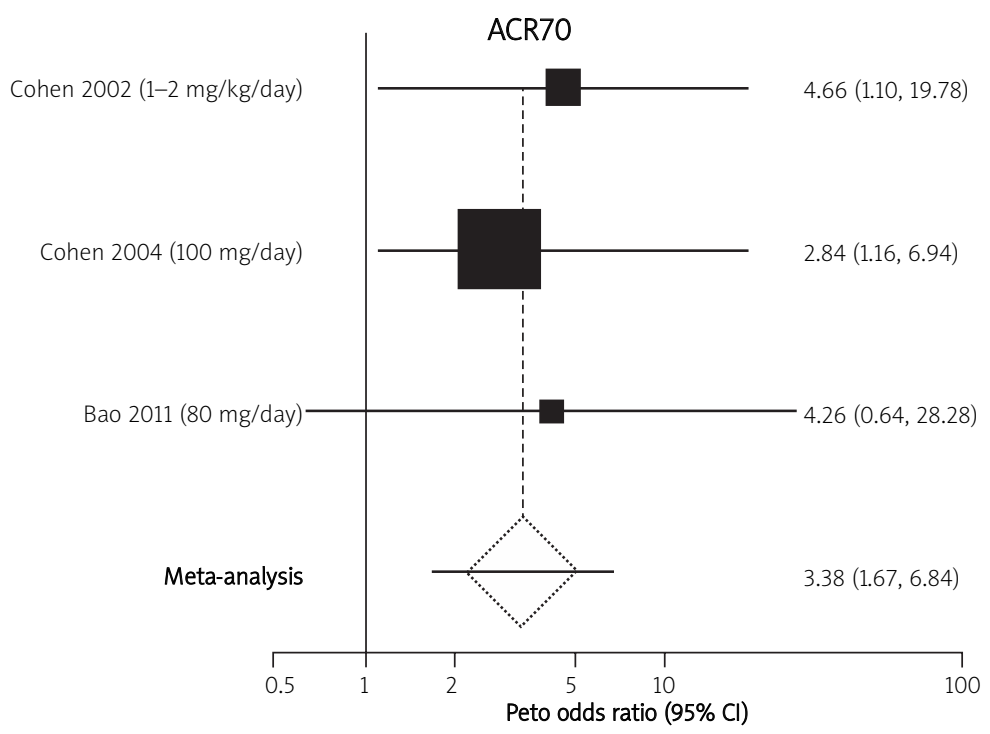

Fig. 1. ACR70 response - meta-analysis. 


\section{Overall adverse events}

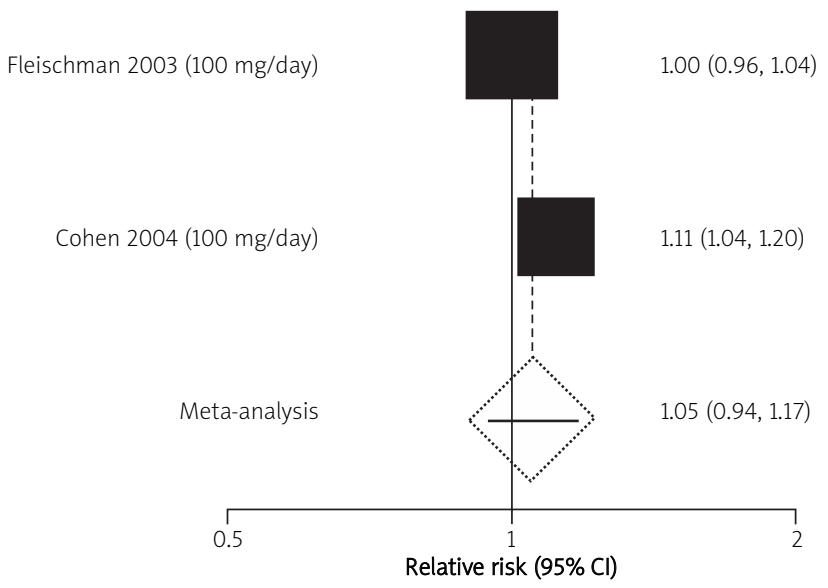

Fig. 2. Overall adverse events - meta-analysis.

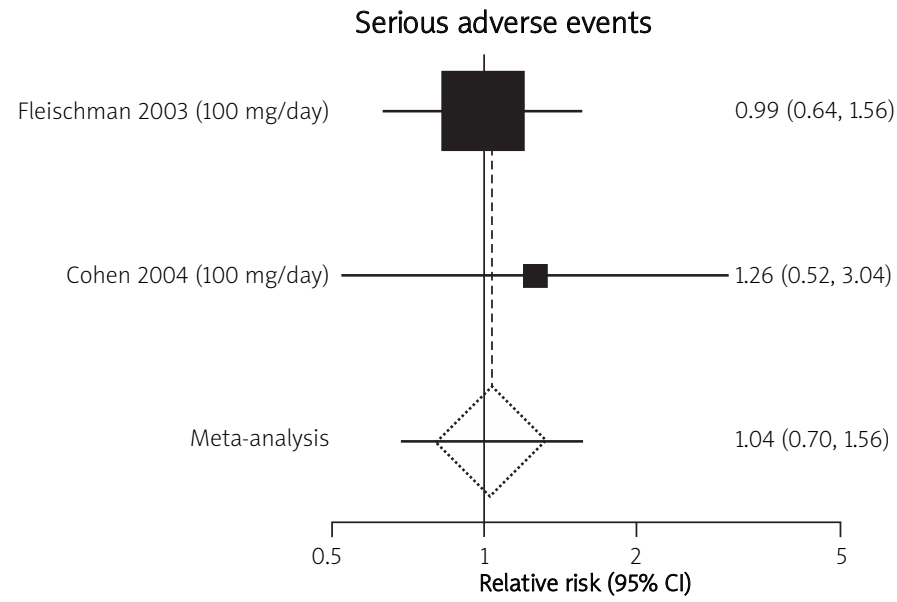

Fig. 3. Serious adverse events - meta-analysis.

active RA (Fig. 1). The results of the meta-analysis addressing the safety of anakinra administered in doses of 1-2 $\mathrm{mg} / \mathrm{kg}$ b.w. per day and $100 \mathrm{mg} /$ day in combination with methotrexate or other DMARDs indicate that, compared to patients who received a placebo, patients receiving anakinra had a significantly higher incidence of allergic reactions at the site of injection of the drug (injection site reactions - ISR), and of withdrawal from treatment as a result of such reactions, but there were no differences with regard to the overall incidence of adverse events or serious adverse events (Figs. 2 and 3). The results of the meta-analysis indicate that anakinra administered in the above-mentioned doses does not increase the risk for developing adverse events (overall), serious adverse events, infections, or serious infections.

The results of observational studies confirm the effectiveness of treatment with anakinra in combination with MTX or other DMARDs in accordance with ACR20 [19, 20], EULAR [21], and DAS28 criteria [20, 21]. In addition, it was confirmed that anakinra combined with MTX improves patients' functional status assessed using the HAQ questionnaire [21], as well as reducing the number of swollen joints and painful joints, the severity of pain and serum C-reactive protein concentration [20].

The analysis of the safety of anakinra revealed that the most common adverse events following its administration were: allergic reactions at the injection site [20-22], joint pain [22], a worsening of the symptoms of RA [22], and infections $[21,22]$. Severe infections were extremely rare $[20,22]$. The results obtained in observational studies confirm the conclusions drawn from randomized trials.

The results of a study conducted on the basis of an analysis of registers in Britain for patients who received anakinra in combination with other DMARDs revealed that 
anakinra may increase the risk of developing serious infections. In view of this, treating physicians should monitor their patients' condition for such events [23].

\section{Final remarks}

Anakinra received marketing authorization for the treatment of adult patients with RA from the American Food and Drug Administration (FDA) in 2001 and from the European Medicines Agency (EMA) in 2002. In Poland, anakinra is available under the brand name of Kineret ${ }^{\circledR}$ and is indicated for use in combined therapy with MTX to treat the objective and subjective symptoms of RA in adults who failed to achieve a satisfactory response to MTX in monotherapy. The recommended dose of anakinra is $100 \mathrm{mg}$ once daily in the form of subcutaneous injections.

The results of this independent review of medical databases and results of meta-analyses confirm the moderate clinical effectiveness (with regard to the most recent EULAR guidelines [10]) and the safety of anakinra in the abovementioned dose. Adverse effects are generally mild or moderate and serious adverse events (including infections) are very rare. The risk of serious infections (which included events that required hospitalization or intravenous administration of an antibiotic) established by the Fleischman study [17, 18], a cause for alarm, was also analysed in a paper by Salliot et al. [24], which reviewed the increased risk of their occurrence associated with the use of biological drugs. Similarly to the findings of the current review, a meta-analysis of the results of isolated studies, presented in that paper [24], did not demonstrate a statistically significant higher risk of developing serious infections. Attention was drawn to the fact that based on the analysed studies [24], administration of anakinra at a dose of $100 \mathrm{mg} /$ day results in a significantly higher risk of serious infections than with lower doses of the drug or a placebo; however, this risk is closely linked to the presence of co-morbidities [24]. The risk of serious infections associated with administration of anakinra and other biological drugs used in patients with RA in combination with DMARDs does not appear to be high. Nonetheless, it should be kept in mind by treating physicians [23].

The authors of this paper do not have any obligations that constitute a conflict of interest. The study was conducted without any financial support.

\section{References}

1. Kontny E. Patogeneza reumatoidalnego zapalenia stawów. Część I - odpowiedź nabyta, uwarunkowania genetyczne i środowiskowe. Reumatologia 2011; 49: 47-54.
2. Tłustochowicz W, Brzosko M, Filipowicz-Sosnowska A i wsp. Stanowisko Zespołu Ekspertów Konsultanta Krajowego ds. Reumatologii w sprawie diagnostyki i terapii reumatoidalnego zapalenia stawów. Reumatologia 2008; 46: 111-114.

3. Rell-Bakalarska M. Osteoporoza w reumatoidalnym zapaleniu stawów. Postępy Nauk Medycznych 2008; 6: 381-388.

4. Mackiewicz S. Reumatoidalne zapalenie stawów - aspekty immunobiologiczne. Reumatologia 2011; 49: 223-230.

5. Rooney M, Symons JA, Duff GW. Interleukin 1 beta in synovial fluid is related to local disease activity in rheumatoid arthritis. Rheumatol Int 1990; 10: 217-219.

6. Furst DE. Anakinra: review of recombinant human interleukinI receptor antagonist in the treatment of rheumatoid arthritis. Clin Therapeutics 2004; 26: 1960-1975.

7. Charakterystyka produktu leczniczego Kineret ${ }^{\circledR}$ (anakinra), kwiecień $2002 \mathrm{r}$.

8. Załącznik B.33. do Obwieszczenia MZ z dnia 25 kwietnia $2012 \mathrm{r}$.

9. Bijlsma MD, Bijlsma J. Optymalne leczenie reumatoidalnego zapalenia stawów - zalecenia EULAR dla praktyki klinicznej. Medycyna Praktyczna 2010; 9: 35-49.

10. Smolen J, Landewé R, Breedveld FC, et al. EULAR recommendations for the management of rheumatoid arthritis with synthetic and biological disease-modifying antirheumatic drugs. Ann Rheum Dis 2010; 69: 964-975.

11. Wytyczne Cochrane Collaboration, www.cochrane.org, kwiecień $2012 \mathrm{r}$.

12. Wytyczne oceny technologii medycznych HTA, www.aotm.gov.pl, kwiecień 2012 r.

13. Cohen S, Hurd E, Cush J, et al. Treatment of rheumatoid arthritis with anakinra, a recombinant human interleukin-1 receptor antagonist, in combination with methotrexate: results of a twenty-four-week, multicenter, randomized, double-blind, placebo-controlled trial. Arthritis Rheum 2002; 46: 614-624.

14. Cohen SB, Woolley JM, Chan W; Anakinra 960180 Study Group. Interleukin 1 receptor antagonist anakinra improves functional status in patients with rheumatoid arthritis. J Rheumatol 2003; 30: 225-231.

15. Cohen SB, Moreland LW, Cush JJ, et al.; 990145 Study Group. A multicentre, double blind, randomised, placebo controlled trial of anakinra (Kineret), a recombinant interleukin 1 receptor antagonist, in patients with rheumatoid arthritis treated with background methotrexate. Ann Rheum Dis 2004; 63: 1062-1068.

16. Bao J, Yue T, Liu W, et al. Secondary failure to treatment with recombinant human IL-1 receptor antagonist in Chinese patients with rheumatoid arthritis. Clin Rheumatol 2011; 30: 697-701.

17. Fleischmann RM, Schechtman J, Bennett R, et al. Anakinra, a recombinant human interleukin-1 receptor antagonist ( $r$-metHulL$1 \mathrm{ra})$, in patients with rheumatoid arthritis: A large, international, multicenter, placebo-controlled trial. Arthritis Rheum 2003; 48: 927-934.

18. Tesser J, Fleischmann R, Dore R, et al.; 990757 Study Group. Concomitant medication use in a large, international, multicenter, placebo controlled trial of anakinra, a recombinant interleukin 1 receptor antagonist, in patients with rheumatoid arthritis. J Rheumatol 2004; 31: 649-654. 
19. Niu X, He D, Deng S, et al. Regulatory immune responses induced by IL-1 receptor antagonist in rheumatoid arthritis. Mol Immunol 2011; 49: 290-296.

20. Karanikolas G, Charalambopoulos D, Vaiopoulos G, et al. Adjunctive anakinra in patients with active rheumatoid arthritis despite methotrexate, or leflunomide, or cyclosporin-A monotherapy: a 48-week, comparative, prospective study. Rheumatology (Oxford) 2008; 47: 1384-1388.

21. Le Loët $X$, Nordström $D$, Rodriguez $M$, et al. Effect of anakinra on functional status in patients with active rheumatoid arthritis receiving concomitant therapy with traditional disease modifying antirheumatic drugs: evidence from the OMEGA Trial. J Rheumatol 2008; 35: 1538-1544.

22. den Broeder AA, de Jong E, Franssen MJ, et al. Observational study on efficacy, safety, and drug survival of anakinra in rheumatoid arthritis patients in clinical practice. Ann Rheum Dis 2006; 65: 760-762.

23. Galloway JB, Hyrich KL, Mercer LK, et al.; BSRBR Control Centre Consortium, Symmons DP; British Society for Rheumatology Biologics Register. The risk of serious infections in patients receiving anakinra for rheumatoid arthritis: results from the British Society for Rheumatology Biologics Register. Rheumatology (Oxford) 2011; 50: 1341-1342.

24. Salliot C, Dougados M, Gossec L. Risk of serious infections during rituximab, abatacept and anakinra treatments for rheumatoid arthritis: meta-analyses of randomised placebo-controlled trials. Ann Rheum Dis 2009; 68: 25-32. 